\title{
The Use of Solar Cell in Ground Water Irrigation to Support Agricultural Cultivation in Rainfed Field
}

\author{
Delvi Yanti

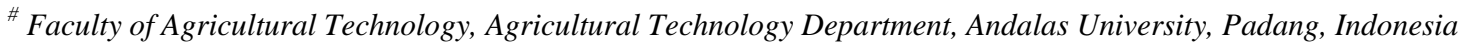 \\ E-mail: delviyanti23@gmail.com
}

\begin{abstract}
This research aims at developing the use of solar cell to water the ground water irrigation in order to support agricultural cultivation in rain-fed field. The location of this research was agricultural land (ricefield) in Singkarak village, $X$ Koto Singkarak subdistrict, Solok district. This research was conducted with the design and technical test of ground water irrigation with solar cell, the analysis of irrigation water demand with crop-wat and the analysis of financial feasibility. The result of analysis showed that the potential of solar energy in Singkarak village could be used to activate the water pump of irrigation. The result of measurement showed that battery which its capacity was $12 \mathrm{~V}$ and $100 \mathrm{Ah}$ needed four hours to be charged by five units of $50 \mathrm{Wp}$ panel PV. Battery as the source of power was able to activate water pump of 125 Watt for 7,52 hours and mean debit that was able to be pumped is 17,45 litre/minute. From 24 periods of plantation time planned in rain-fed field, there were only three periods of plantation that the operational hours of their water pumps were able to be covered by the battery namely January 2, February 2 , and November 2. Based on the result of financial analysis, these three periods of plantation were financially feasible in their implementation because the value of $B / C$ ratio $>1$ and $N P V>0$.
\end{abstract}

Keywords - agricultural cultivation; irrigation; ground water; rain fed field; solar cell

\section{INTRODUCTION}

The improvement of wet-rice field productivity is a popular issue nowadays. The existence of food tenacity program that aims at fulfilling people's need becomes a problem that needs to be overcome as soon as possible. Therefore the increase of rice productivity is needed in order to increase the food tenacity of district or region.

There are various ways done in order to increase food production namely extensification, diversification, and intensification. Extensification is an effort to increase food production by widening the area of plantation. Diversification is an effort to diversify plants grown in a field. Intensification is an effort to improve food production by applying intensive ways to an already existed field, such as the use of prime seed, the giving of appropriate fertilizer, and the effective and efficient distribution of irrigation water.

According to the National Policy of Indonesia Water Resource of year 1994-2020, it emphasizes on improving the efficiency and even distribution of surface water and ground water in supporting the process of plant production. The transfer of water management results on the ineffective and inefficient distribution of irrigation water, particularly on rain-fed field. The obstruction of farming development of rain-fed field is the limited amount of rainfall. Meanwhile when the irrigation of rain-fed field is activated by using water pump, the operational cost of activating this water pump is expensive, because it needs fuel to operate it.

The technology and equipment of water pump is available and easy to access, but the fuel used as the activator energy of water pump sometimes becomes an obstacle from both of its availability and price. The cost of buying fuel becomes an operational cost that must be spent by the farmers. At certain times, this operational cost makes the farmers worry because it coincides with other production costs. The use of solar cell to activate the water pump is one of solutions to decrease the operational cost that must be spent by the farmers.

Solar cell is the most promising source of energy because its sustainable characteristics and vast amounts. Sun is the source of energy expected to overcome the problem of future energy after the various sources of conventional energy reduces in amount and are not environment friendly. The technology system of solar cell used in water pump does not need fuel, so it does not need any contribution from water users and any operator to operate it. It is also categorized as a long-lasting item.

Making effective use of the ground water by using solar cell becomes one of solutions for the irrigation problem of rain-fed field. Although ground water is renewable resource, 
it is a resource that can be used up and damaged. Unlike surface water, the management of ground water must be done carefully since the depletion and degradation of ground water cannot be restored perfectly. Ground water can be used continuously if its extraction can be limited as big as the ability of recharge capacity.

This research aims at developing the use of solar cell to water the ground water irrigation in order to support agricultural cultivation in rain-fed field.

\section{RESEARCH METHODS}

This research was conducted with the design and technical test of ground water irrigation with solar cell, the analysis of irrigation water demand with crop-wat and the analysis of financial feasibility. Data needed in this research involved: (a) the data of agroclimate for this ten years, the data of the kind of cultivated plant, and the data of soil; (b) the data of waterpump: the rate of flow of waterpump and the operation hours of waterpump; (c) the data of battery and solar panel; and (d) the data of production cost. The data were collected through direct field observation and interview.

\section{A. The Design and Operation of Waterpump}

Determining the operational system of ground water irrigation was depended highly on the capacity of energy source and the capacity of solar panel in catching sunray. The operation activity of waterpump was determined by calculating the need of irrigation water that must be supplied, and it was calculated by using the following equation:

$$
\begin{aligned}
& \text { The Time of aperating waterpump }\left(\frac{h a w r}{d a y}\right) \\
& =\frac{\text { The need of irrigation water }\left(\frac{\text { firm }}{d g y}\right)}{\text { Waterpump's rate of flow (hitrehour? }}
\end{aligned}
$$

\section{B. The Measurement of The Need of Irrigation Water}

The distribution of irrigation water could be viewed as the need of irrigation water minus effective rain and the contribution of ground water. The need of irrigation water was calculated by using crop-wat software applied to 24 plans of planting time.

\section{The Technical Analysis of Ground Water Irrigation of Solar Cell}

The technical analysis of ground water irrigation that were conducted involved:

The rate of flow that was able to be produced by waterpump was calculated by using the equation:

$$
\text { Rate of Flow ( hitre })=\frac{\text { water polume (itre) }}{\text { Time minute) }}
$$

The operational hours of waterpump that was able to be supplied by energy source (battery) was calculated by using the equation:

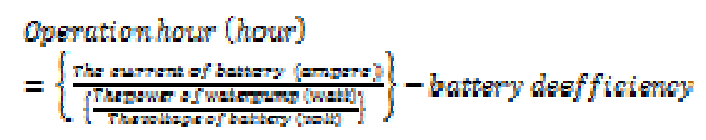

The charging time of battery

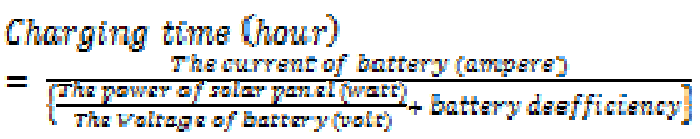

Note: Battery deefficiency is $20 \%$ of needed current.

\section{The Financial Analysis of Ground Water Irrigation of Solar Cell}

Istalaksana et al [1] stated, criteria used in conducting an evaluation toward the investment of project are: 1) NPV (Net Present Value), 2) IRR (Internal Rate off Return), 3) Net B/C (Net Benefit-Cost Ratio), 4) PBP (Pay Back Period). A production activity is stated feasible when the value of NPV (Net Present Value) $>0$ or the value of $\mathrm{B} / \mathrm{C}$ ratio $>1$. Financial feasibility can be known from the following equations:

$$
\begin{aligned}
& N V P=\sum_{t=1}^{n} \frac{E_{1}-G_{1}}{\left(1+\sum^{2}\right.} \\
& \frac{g}{G} \text { ratio }=\frac{\sum_{z-1}^{n} \frac{E_{2}}{(1-1)^{2}}}{\sum_{t-1}^{n} \frac{C_{t}}{(1+1)^{2}}}
\end{aligned}
$$

Explanation:

$$
\begin{array}{ll}
\mathrm{NVP} & =\text { net present value }(\mathrm{Rp}) \\
\mathrm{Bt} & =\text { In cash-flow in year-t }(\mathrm{Rp}) \\
\mathrm{Ct} & =\text { Out cash-flow in year-t }(\mathrm{Rp}) \\
\mathrm{t} & =\text { Year-t } \\
\mathrm{i} & =\text { The level of interest (\%/year) } \\
\mathrm{n} & =\text { The economical age of equipment (year) }
\end{array}
$$

\section{RESULTS AND DISCUSSION}

\section{A. The Description of Research Location}

Research location was the rain-fed field of agricultural land of Singkarak village stated as part of governmental region of X Koto Singkarak sub-district, Solok district. Geographically, Singkarak village is at $0^{\circ} 42^{\prime} 05^{\prime \prime}$ of South Latitude and $100^{\circ} 43^{\prime} 40^{\prime \prime}$ of East Longitude. The climate situation of Singkarak village could be found in Table 1. Based on the analysis of soil sample, the kind of soil found in the location of research was clayey.

All elements of climate affected the amount of irrigation water needed by agricultural land. The work of ground water irrigation was determined by sun radiation and the time of sun radiation. The mean of time of sun radiation was $37,38 \%$ or 4,13 hours/day. It meant that the mean of time of sun radiation changed into electrical power for a day was 4,13 hours. The mean affectivity of sun's ray time to radiate in tropical country like Indonesia is 5 hours. The result of five hours has become a kind of calculation of standard equation of sun's ray affectivity absorbed by solar panel [2]. 
TABLE I

The Data Of RaINFALl, Wind Velocity, Humidity, Temperature, AND SUN RADIATION OF TESTING LOCATION

\begin{tabular}{|l|c|c|c|c|c|c|}
\hline Month & $\begin{array}{c}\text { Rainfall } \\
(\mathrm{mm})\end{array}$ & $\begin{array}{c}\text { Wind } \\
\text { velocity } \\
(\mathrm{km} / \text { day })\end{array}$ & $\begin{array}{c}\text { Humidity } \\
(\%)\end{array}$ & $\begin{array}{c}\text { Min } \\
\text { temp } \\
\left({ }^{\circ} \mathrm{C}\right)\end{array}$ & $\begin{array}{c}\text { Max } \\
\text { temp } \\
\left({ }^{\square} \mathrm{C}\right)\end{array}$ & $\begin{array}{c}\text { Sun } \\
\text { radiation } \\
(\%)\end{array}$ \\
\hline January & 238,15 & 27,88 & 99,57 & 25,38 & 35,70 & 31,68 \\
\hline February & 183,24 & 26,78 & 99,65 & 25,94 & 36,05 & 36,08 \\
\hline March & 202,41 & 30,17 & 99,65 & 26,88 & 37,65 & 39,96 \\
\hline April & 208,39 & 28,17 & 99,72 & 26,81 & 37,80 & 46,97 \\
\hline May & 185,05 & 26,41 & 99,77 & 27,88 & 37,50 & 49,02 \\
\hline June & 89,60 & 26,42 & 99,73 & 26,81 & 36,10 & 34,66 \\
\hline July & 96,19 & 28,31 & 99,70 & 25,25 & 36,50 & 44,90 \\
\hline August & 128,48 & 27,93 & 99,56 & 25,13 & 35,90 & 31,79 \\
\hline September & 152,41 & 30,34 & 99,45 & 26,69 & 36,94 & 38,20 \\
\hline October & 155,23 & 30,30 & 99,38 & 27,81 & 39,69 & 33,54 \\
\hline November & 241,11 & 25,49 & 99,47 & 25,88 & 37,38 & 32,35 \\
\hline December & 230,14 & 21,34 & 99,43 & 25,88 & 34,81 & 29,44 \\
\hline
\end{tabular}

\section{B. The Need of Irrigation Water}

Many factors affected the distribution of irrigation water. One of factors that affected was planting time. For one period of planting season (140 days), the area of 0,691761 ha needed different amount of irrigation water. The data of the need of irrigation water for one period of planting season could be found in table 2 . The lowest the rainfall the highest the evapotranspiration, this resulted on the highest the demand of irrigation water and this would happen reversely. Based on the arranged time of planting period, the highest demand of irrigation water was June 1 (Table 2) and this month was month with the lowest rainfall (Table 1).

TABLE II

The NeEd Of IRrigation Water Based On The Period OF Planting TiMe

\begin{tabular}{|l|c|}
\hline Planting Time & The Need of Irrigation Water (litre/day) \\
\hline January 1 & $11.517,82$ \\
\hline January 2 & $6.655,73$ \\
\hline February 1 & $11.601,82$ \\
\hline February 2 & $7.367,25$ \\
\hline March 1 & $10.317,12$ \\
\hline March 2 & $11.339,94$ \\
\hline April 1 & $14.383,69$ \\
\hline April 2 & $10.816,18$ \\
\hline May 1 & $13.237,34$ \\
\hline May 2 & $13.924,16$ \\
\hline June 1 & $15.910,50$ \\
\hline June 2 & $11.819,23$ \\
\hline July 1 & $12.051,46$ \\
\hline July 2 & $12.733,34$ \\
\hline August 1 & $14.536,86$ \\
\hline August 2 & $9.551,24$ \\
\hline September 1 & $12.881,58$ \\
\hline September 2 & $8.315,96$ \\
\hline October 1 & $9.595,71$ \\
\hline October 2 & $9.768,65$ \\
\hline November 1 & $11.320,17$ \\
\hline November 2 & $7.125,14$ \\
\hline December 1 & $8.968,19$ \\
\hline December 2 & $8.938,54$ \\
\hline
\end{tabular}

The different amount of irrigation water needed was constituted by the factor of climate. Reference [3] shows that during the growth of plant, the cumulative amount of evapotranspiration that must be filled by irrigation water was affected by plant type, solar radiation, irrigation system, growth period, rain, and other factors. The amount of water transpired by plant was depended on the amount of moisture that was available in the area of root, temperature and air humidity, wind velocity, the intensity and duration of radiation, the phase of growth, and the types of leaves.

\section{The Result of Technical Test of Ground Water Irrigation with Solar Cell}

Water pump used for ground water irrigation had the charge value of 125 watt, while the source of energy (battery) used had the capacity of 12 volt and $10 \mathrm{Ah}$. Based on the capacity of given battery, water pump was able to operate for 7,52 hours, with the value of Depth of Discharge (DoD) of battery of $80 \%$.

Depth of Discharge (DoD) is a definition that determines the limit of depth of discharge existed in the battery. Instead of giving the depth of DoD output value of $100 \%$, battery factory always rates the DoD value of battery for $80 \%$, it means that only $80 \%$ of available energy that can be used up while the other $20 \%$ is kept inside the battery (battery deficiency of 20\%). Battery that was not fully used-up until zero will prevent the damaging of battery and lengthen the life of battery [4].

Solar panel used in this research could change photon (of sun's ray) into the electricity of $50 \mathrm{Wp}$, so to fill the battery of 12 volt and $100 \mathrm{Ah}$ was needed 5 units of solar panel and time used to fully charge the battery (the $20 \%$ of battery deficiency) was 4 hours. In the research location, the average time of sun radiation was 4,13 hours/day (Table 1I, and it means that the need of battery charging could be fulfilled. The data of testing result of irrigation water pump would be given in Table 3.

Based on the Table 3, the average discharge of water pump was 17,45 litre/minute. This condition was still below the specification of water pump that its maximum discharge of water was 30 litre/minute. Reference [5] shows, the results of research that has been done that the average discharge of water that flowed out from the water pump of 60 watt during testing time was 227 litre/hour. This condition was still below the specification of water pump that its maximum discharge of water was 2400 litre/hour. This showed that inverter was not able to keep the constant flow of AC current.

TABLE III

The DATA Of RATE Of Flow Of Ground WATER IRrigation WITH SOLAR CELL

\begin{tabular}{|c|c|c|c|}
\hline Repetition & $\begin{array}{c}\text { Volume } \\
\text { (litre) }\end{array}$ & $\begin{array}{c}\text { Time } \\
\text { (minute) }\end{array}$ & $\begin{array}{c}\text { Rate of flow } \\
\text { (litre/minute) }\end{array}$ \\
\hline 1 & 25 & 1,37 & 18,29 \\
\hline 2 & 25 & 1,38 & 18,07 \\
\hline 3 & 25 & 1,43 & 17,44 \\
\hline 4 & 25 & 1,43 & 17,44 \\
\hline 5 & 25 & 1,45 & 17,24 \\
\hline 6 & 25 & 1,45 & 17,24 \\
\hline 7 & 25 & 1,45 & 17,24 \\
\hline 8 & 25 & 1,45 & 17,24 \\
\hline 9 & 25 & 1,45 & 17,24 \\
\hline 10 & 25 & 1,47 & 17,05 \\
\hline \multicolumn{3}{|c|}{ Average value } & 17,45 \\
\hline
\end{tabular}

The operational hours of water pump for every planting time were depended on the amount of irrigation water 
needed and the rate of flow produced by water pump. The amount of operational hours that based on planting time would be given in Table 4.

TABLE IV

The Operational Hours OF WATER PUMP BASEd ON Planting Time

\begin{tabular}{|l|c|c|c|}
\hline $\begin{array}{c}\text { Planting } \\
\text { Time }\end{array}$ & $\begin{array}{c}\text { The Need of } \\
\text { Irrigation Water } \\
\text { (litre/day) }\end{array}$ & $\begin{array}{c}\text { The Rate of } \\
\text { Flow of } \\
\text { Waterpump } \\
\text { (litre/hour) }\end{array}$ & $\begin{array}{c}\text { The Operational } \\
\text { Hours of } \\
\text { Waterpump } \\
\text { (hour/day) }\end{array}$ \\
\hline January 1 & $11.517,82$ & 1.047 & 11,00 \\
\hline January 2 & $6.655,73$ & 1.047 & $6,36^{*}$ \\
\hline February 1 & $11.601,82$ & 1.047 & 11,08 \\
\hline February 2 & $7.367,25$ & 1.047 & $7,04^{*}$ \\
\hline March 1 & $10.317,12$ & 1.047 & 9,85 \\
\hline March 2 & $11.339,94$ & 1.047 & 10,83 \\
\hline April 1 & $14.383,69$ & 1.047 & 13,74 \\
\hline April 2 & $10.816,18$ & 1.047 & 10,33 \\
\hline May 1 & $13.237,34$ & 1.047 & 12,64 \\
\hline May 2 & $13.924,16$ & 1.047 & 13,30 \\
\hline June 1 & $15.910,50$ & 1.047 & 15,20 \\
\hline June 2 & $11.819,23$ & 1.047 & 11,29 \\
\hline July 1 & $12.051,46$ & 1.047 & 11,51 \\
\hline July 2 & $12.733,34$ & 1.047 & 12,16 \\
\hline August 1 & $14.536,86$ & 1.047 & 13,88 \\
\hline August 2 & $9.551,24$ & 1.047 & 9,12 \\
\hline September 1 & $12.881,58$ & 1.047 & 12,30 \\
\hline September 2 & $8.315,96$ & 1.047 & 7,94 \\
\hline October 1 & $9.595,71$ & 1.047 & 9,16 \\
\hline October 2 & $9.768,65$ & 1.047 & 9,33 \\
\hline November 1 & $11.320,17$ & 1.047 & 10,81 \\
\hline November 2 & $7.125,14$ & 1.047 & $6,81^{*}$ \\
\hline December 1 & $8.968,19$ & 1.047 & 8,57 \\
\hline December 2 & $8.938,54$ & 1.047 & 8,54 \\
\hline Plang & & \\
\hline
\end{tabular}

*) Planting time that its operational hour was able to be filled by the battery as the source of energy

Based on the Table 4, it could be seen that from 24 scenarios of planting time, there were only 3 scenarios of planting time that their operational hours were able to be fulfilled by battery namely January 2, February 2, and November 2 . This is because the battery with the capacity of 12 Volt and 100 Ah was only able to activate the water pump of 125 watt for 7,52 hours.

\section{The Financial Analysis of Ground Water Irrigation by Using Solar Cell}

The implementation of ground water irrigation by using solar cell becomes one of alternative solutions to fulfil the need of irrigation water of rain-fed field, but it is still uncertain whether this implementation will financially give advantage to the farmers or not. Reference [6] stated, the conventional approach conducted during the process of discussing the financial feasibility of project and investment is by analysing the prediction of in and out cash flows as long as the project age. In the financial analysis of implementing the use of solar cell in ground water irrigation, it does not use project age but economical age, because in the process of calculation, there is no reinfestation. Assets such as office equipment and several kinds of production equipment's have economical age that is smaller than project age namely 3-5 years.

The feasibility analysis of ground water irrigation of solar cell was only conducted to the planting months that their operational hours were able to be fulfilled by the battery. The result of financial analysis would be given in Table 5 .

TABLE V

The Result Of FinANCIAL ANALysis OF GROUND WATER IRRIGATION OF SOLAR CELL

\begin{tabular}{|l|c|c|}
\hline \multicolumn{1}{|c|}{ Planting Time } & NPV & B/C Ratio \\
\hline January 2 & $3.158 .137,91$ & 1,11 \\
\hline February 2 & $2.335 .312,67$ & 1,08 \\
\hline November 2 & $2.615 .301,82$ & 1,09 \\
\hline
\end{tabular}

Net Present Value (NPV) is the difference of present value benefit and present value cost. The values of NPV for every planting time with the discount factor of $11 \%$ were Rp. 3.158.137,91 (January 2), Rp 2.335.312,67 (February 2), and Rp 2.615.301,82 (November 2). These values showed the received net benefit of the next five years, when they were measured by current value. The NPV of three recommended periods of planting time showed the positive number, so the investment was stated financially feasible.

Net Benefit Cost Ratio (Net B/C) is the comparison value of positive NPV and negative NPV. The values of Net B/C for every planting time were 1,11 (January 2), 1,08 (February 2), and 1,09 (November 2). The values of Net B/C for all of three periods of planting time recommended were bigger than 1 , so the investment was stated financially feasible

\section{CONCLUSIONS}

The result of analysis showed that the potential of solar cell in Singkarak village can be used to activate the water pump of irrigation. The result of measurement showed that battery with the capacity of 12 volt and 100 Ah needed 4 hours to be charged by 5 units of PV panel of $50 \mathrm{Wp}$. Battery as the source of energy was able to activate the water pump of 125 watt for 7,52 hours and the mean rate of flow that was able to be pumped was 17,45 litre/minute. In the implementation, from 24 periods of planting time scheduled in rain-fed field, there were only three periods of planting time that their operational hours were able to be fulfilled by the battery, namely January 2, February 2, and November 2. Based on the financial analysis, these three periods of planting time could be stated financially feasible in their implementation because the value of $\mathrm{B} / \mathrm{C}$ ratio $>1$ and the value of $\mathrm{NPV}>0$.

\section{REFERENCES}

[1] Istalaksana dan Paulus Payung. 2013. Rancang Bangun dan Evaluasi Tekno-Ekonomi Alat Perontok Pokem (Setaria Italica). Jurnal Teknologi Pertanian Vol. 14 No. 3. [Desember 2013] 209-214

[2] Anonim. 2015. Pembangkit Listrik Tenaga Surya. http://dayasurya.weebly.com (diakses tanggal 19 September 2015)

[3] Anonim. 2015. Bagaimana Bikin Listrik di Rumah Pakai Solar Panel. http://greenlifestyle.or.id/. (diakses tanggal 19 September 2015)

[4] Kalsim, Dedi Kusnadi., Budi Indra Setiawan, Asep Sapei, Prastowo, Erizal. 2006. Perancangan Irigasi dan Drainase Interaktif Berbasis Teknologi Informasi. Departemen Teknik Pertanian. Fakultas Teknologi Pertanian. Institut Pertanian Bogor. Bogor.

[5] Zaini dan Dahlan. 2012. Analisis Pemanfaatan Pompa Air Tenaga Surya untuk Pengembangan Irigasi Air Tanah. Jurusan Teknik Mesin, Politeknik Negeri Lhokseumawe

[6] Soeharto, Iman. 1998. Manajemen Proyek: Dari Konseptual Sampai Operasional (Jilid 1). Edisi Kedua. Erlangga, Jakarta. 